\title{
Isparta Kent Merkezindeki Bazı İlkokulların Dış Çevre Gürültülerinin İncelenmesi Üzerine Bir Araştırma
}

\author{
Büşra ONAY ${ }^{1}$, Candan KUŞ ŞAHIN ${ }^{1 *}$ \\ ${ }^{1}$ Süleyman Demirel Üniversitesi, Mimarlık Fakültesi, Peyzaj Mimarlığı Bölümü, 32260, Isparta
}

\section{Öz}

Okullar; öğrencilerin eğitim aldıkları ve geleceklerini şekillendirdikleri alanlardır. Okullarda eğitimin sağlıklı bir şekilde devam edebilmesi için okul bahçeleri, dış mekanla okul arasında tampon görevi görmektedir. Kentsel açık yeşil alan birimlerinden birisi olarak kabul edilen okul bahçeleri; çocukların okul zamanı içinde ve dişında kullandıkları, kentleri açık yeşil alan bakımından bir miktar da olsa rahatlatan alanlar olarak gösterilmektedir. Okul bahçeleri, çocukların hem eğitim aldıkları hem de serbest zamanlarında vakit geçirdikleri alanlar olduğu için kullanım yoğunluğu oldukça fazladır. Bu yüzden, okul bahçelerinde ve çevresinde yaşanacak çevre sorunlarının en aza indirilmesi gerekmektedir. Bu çalışmada, Isparta kent merkezinde seçilen 4 resmi ilkokulda okul bahçesinde ve bahçe dışında, gürültü düzeyinin belirlenmesi amacıyla ölçümler yapılmış ve ölçüm verilerinden yararlanılarak gürültü haritaları hazırlanmıştır. Çalışma yapılacak olan okulların belirlenmesinde; kent merkezine yakın olmaları, öğrenci sayıları, bahçe büyüklükleri ve çevresindeki kullanımlar dikkate alınmıştır. Ölçümler, okullarda eğitim öğretimin devam ettiği hafta içi ve 08.30-17.00 saatleri arasında 5 dakika süre boyunca yapılmıştır. Ölçümlerin her noktada farklı gün ve saatlerde alınmasına dikkat edilmiştir. Ölçümler için her okulda teneffüste bahçe içinde, teneffüste bahçe dışında ve ders esnasında bahçe dışında olmak üzere belirlenen noktalardan üç ölçüm yapılmıştır. Elde edilen sonuçlar, WHO tarafından belirlenen okul bahçeleri çevresindeki gürültü sınır değerleriyle karşılaştırılmıştır. Çalışmanın sonucunda, tüm okullarda Leq değerinin $55 \mathrm{~dB}(\mathrm{~A})$ üzerinde olduğu görülmüştür. Bu değerin WHO tarafından belirlenen okul bahçeleri çevresindeki gürültü sınır değerinin $(55 \mathrm{~dB}(\mathrm{~A}))$ üzerinde olması nedeniyle, okul çevrelerinde önlem alınması gerektiği sonucuna varılmıştır.

Anahtar Kelimeler: Gürültü, Isparta, ilkokul, okul bahçesi.

\section{A Research on the Investigation of Outdoor Noise of Some Primary Schools in Isparta City Center, Turkey}

\begin{abstract}
Schools are areas where the students are received education and develop their future. In order to be following healthy progress in education, school gardens, are a buffer between the outdoor space and the school. School gardens, which are considered as one of the urban open green space units; children use in and out of school time, which relieves cities to some extent. Since school gardens are areas where children both get education and spend time in their free time, usage density is quite high. Therefore, it is necessary to minimize the environmental problems to be experienced in and around the school gardens. In this study, the noise levels of selected four official primary schools' gardens, located in Isparta city center and their surroundings were measured and noise maps were prepared with measured results. While determining the schools, the distance from city center, student populations, the size of the garden and usage of surroundings have been taken into account. The measurements were made during education in progress between 8.30-17.00 in weekdays for five min. of durations. However, an attention was considered that measurements were made in same location but different day and hours. The experiments were conducted at selected points for three measurements that during break time in schoolyard, during break time out of schoolyard and during class time. The collected data were compared with WHO suggested noise level limits for schoolyard surroundings. At the end of study, all selected school's Leq values were found to be higher than 55 $\mathrm{dB}(\mathrm{A})$. Due to the fact that the measured values are above the noise limits $(55 \mathrm{~dB})$ which suggested by World Health Organization (WHO) for schools, it was concluded that precautions should be taken in school environments.
\end{abstract}

Keywords: Noise, Isparta, primary school, school garden.

\footnotetext{
*Sorumlu Yazar (Corresponding Author): 


\section{Giriş}

Kentleşme, sanayileşme ve teknolojik gelişmelerin ilerlemesiyle ortaya çıkan çevre sorunları, çözüm aranılması gereken sorunlardır. Hava kirliliği, su kirliliği, iklimde meydana gelen değişimler, biyolojik çeşitliliğin yok olması, ozon tabakasının incelmesi ve gürültü kirliliği gibi çeşitli çevre sorunları, sağlıklı bir dünya için önlem alınması gereken sorunlar arasındadır (Cansaran, 2019).

Kentlerin büyük bir çoğunluğunu etkileyen çevre sorunlarından birisi olan gürültü kısaca; istenmeyen, rahatsız edici ses olarak tanımlanmaktadır (Kurra, 2009). Gürültü; psikolojik ve fizyolojik dengeleri bozabilen, iş performansında düşüşe neden olan, toplumun işitme sağlı̆ııı ve algılamasını olumsuz yönde etkileyen, çevrenin sakinliğini ve hoşluğunu yok ederek niteliğini değiştiren önemli bir çevre kirliliği türü olarak tanımlanmaktadır (Yerli, 2012).

Kentsel açık yeşil alanların birimlerinden birisi olarak kabul edilen okul bahçeleri; çocukların okul zamanı içinde ve dışında kullandıkları, kentleri açık yeşil alan bakımından bir miktar da olsa rahatlatan alanlar olarak gösterilmektedir. Okul bahçeleri, çocukların hem eğitim aldıkları hem de serbest zamanlarında vakit geçirdikleri alanlar olduğu için kullanım yoğunluğu oldukça fazladır. Bu yüzden, okul bahçelerinde ve çevresinde yaşanacak çevre sorunlarının en aza indirilmesi gerekmektedir. Okullar; öğrencilerin eğitim aldıkları, geleceklerini şekillendirdikleri alanlardır. Bu eğitimin en iyi şekilde verilebilmesi için uygun şartların sağlanması gerekir. Okullarda verilen eğitimin sağlıklı bir şekilde devam edebilmesi için okul bahçeleri, dış mekanla okul arasında tampon görevi görmektedir.

$\mathrm{Bu}$ çevre sorunlarından birisi olan gürültü kirliliği, okul bahçesinde ve çevresinde farklı kaynaklardan çıkarak öğrenme ve öğretme performansı üzerinde olumsuz etki bırakmaktadır. Bu olumsuz etkiyi azaltmak ya da önlemek amacıyla Dünya Sağlık Örgütü (WHO) tarafından okul binası içinde/dersliklerde 35 dB(A), okul bahçesinde ise $55 \mathrm{~dB}(\mathrm{~A})$ olarak sınır değerleri belirlenmiştir (Kurra, 2009).

Okullardaki fiziksel gürültünün genel olarak iki kaynağı bulunmaktadır. Bunlardan birincisi; kapalı okul alanlarında yapılan taşıma, delme, vurma, çakma gibi işler ile öğrenci konuşmalarından kaynaklanan gürültüler iken, ikincisi ise okul dışından kaynaklanan gürültülerdir (Güremen, 2012a). Okul dışından kaynaklanan gürültülerde, okulun konumu ve çevresinde yer alan kullanımlar önem arz etmektedir. Örneğin Akabay ve Bulunuz (2018) ile Şahin vd. (2014)'nin kent merkezinde ve kent merkezinden uzak olan okullarda yaptıkları çalışmalarda, kent merkezindeki okulların gürültü seviyelerinin trafiğe ve nüfusa bağlı olarak yüksek çıktığ1 sonucuna varılmıştır. Ebrahim vd. (2017) yaptıkları çalışmada, maruz kaldıkları gürültü kaynaklarına göre ilkokul ve ortaokuldan oluşan 6 farklı çalışma alanı seçmişlerdir. Bu çalışmada elde edilen gürültü ölçümleri sonucunda, yoğun trafik akışına sahip yol üzerinde bulunan okulların $70 \mathrm{~dB}(\mathrm{~A})$ ve $81 \mathrm{~dB}(\mathrm{~A})$ gürültü seviyesine maruz kaldıkları tespit edilmiştir.

Fonksiyonu insan yetiştirmek ve eğitmek olan eğitim kurumlarında, gürültünün azaltılması ya da önlenmesi konusunda oldukça hassas yaklaşımların uygulanması önemlidir. İlkokulların, eğitimin ilk ve en önemli kademesini oluşturması ve kullanıcılarının küçük yaştaki çocuklardan oluşması, gürültü sorununun doğru olarak belirlenerek engellenmesi gerekliliğini ve önemini arttırmaktadır (Güremen, 2012a).

Bu çalışmada; Isparta kent merkezinde bulunan, belirli kriterler doğrultusunda seçilmiş olan ilkokullarda, gürültü etkisi incelenmiştir. Bu bağlamda çalışmayla, ilkokulların bahçe içinde ve bahçe dışındaki gürültü seviyelerinin belirlenerek, eğitim-öğretim faaliyetinin iyileştirilmesi için gürültüyü azaltma ve önlemeye yönelik öneriler getirilmesi amaçlanmıştır.

\section{Materyal ve Metot}

\subsection{Materyal}

Akdeniz Bölgesinde Göller Yöresinde yer alan Isparta ili, yaklaşık 8933 km² yüzölçümüne sahiptir. Rakımı ortalama 1050 metredir (Anonim, 2019). 30 20' ve $31^{\circ} 33^{\prime}$ doğu boylamları ile $37^{\circ} 18^{\prime}$ ve $38^{\circ} 30^{\prime}$ kuzey enlemleri arasında yer alan Isparta ili, kuzey ve kuzeybatıdan Afyonkarahisar, batıdan ve güneybatıdan Burdur, güneyden Antalya doğu ve güneydoğudan ise Konya illeri ile çevrilmiştir (Demirci, 2011).

Bu çalışma; Isparta kent merkezinde seçilen Naşide Halil Gelendost İlkokulu, Hafız İbrahim Demiralay İlkokulu, Gazi İlkokulu ve Ülkü İlkokulu bahçe içi ve bahçe dışında gerçekleştirilmiştir. Çalışmayı oluşturan okullar 
belirlenirken; kent merkezine yakın olmasına, öğrenci sayısına, bahçe büyüklüğüne ve çevresindeki kullanımlara dikkat edilerek seçim yapılmıştır. Çalışma alanı olarak seçilen okulların, gürültüye maruz kalmaları açısından, Isparta kent merkezinde yer alan diğer ilkokulların temsili durumunda olduğu değerlendirilmiştir.

Çalışmada yer alan okulların fiziksel özellikleri ayrı ayrı irdelenmiştir. Bu bağlamda seçilen okullardan ilki olan ve Isparta kent merkezinde, Hızırbey Mahallesi'nde yer alan Naşide Halil Gelendost İlkokulu'nun yapımı, 1997 yılında tamamlanmıştır. Okul binası $1562 \mathrm{~m}^{2}$, okul bahçesi ise $5000 \mathrm{~m}^{2}$ alana sahiptir. Kent merkezine uzaklığ 1 km olan okulun öğrenci sayısı 798'dir (URL1 2020). Okul çevresi analiz edildiğinde; güneybatı cephesinde bir adet anaokulunun bulunduğu, diğer cephelerinde ise konutların yer aldığı görülmektedir. Okulun üç tarafında yol yer almaktadır. Kuzeybatısında yer alan yol çift yönlüdür ve aralarında bir refüj bulunmaktadır. Okulun kuzey cephesinde yer alan yol ise diğer yollara göre daha yoğun trafik akışına sahiptir (Şekil 1).
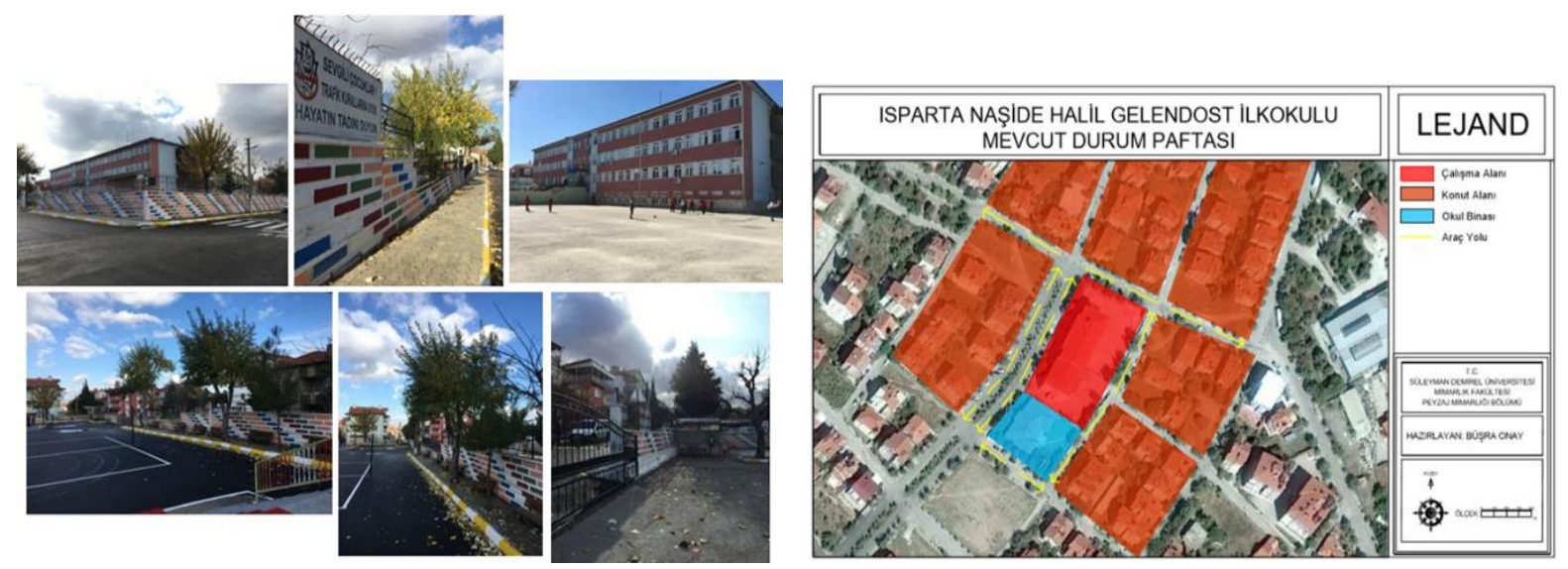

Şekil 1. Naşide Halil Gelendost İlkokulu’ndan görünümler ve konumu.

Isparta kent merkezinde Davraz Mahallesi’nde yer alan Hafız İbrahim Demiralay İlkokulu'nun (HİDİ) yapımı 2004 yılında tamamlanmıştır. $4604 \mathrm{~m}^{2}$ genişliğinde bahçeye sahip olan okulun, 831 adet öğrencisi bulunmaktadır (URL1 2020). Konutlar arasında yer alan okulun kuzeydoğu cephesinde bir mahalle park1 yer almaktadır. Okulun çevresi yollarla çevrilidir (Şekil 2). En fazla trafik akışı kuzeydoğu cephesinde yer almaktadır.
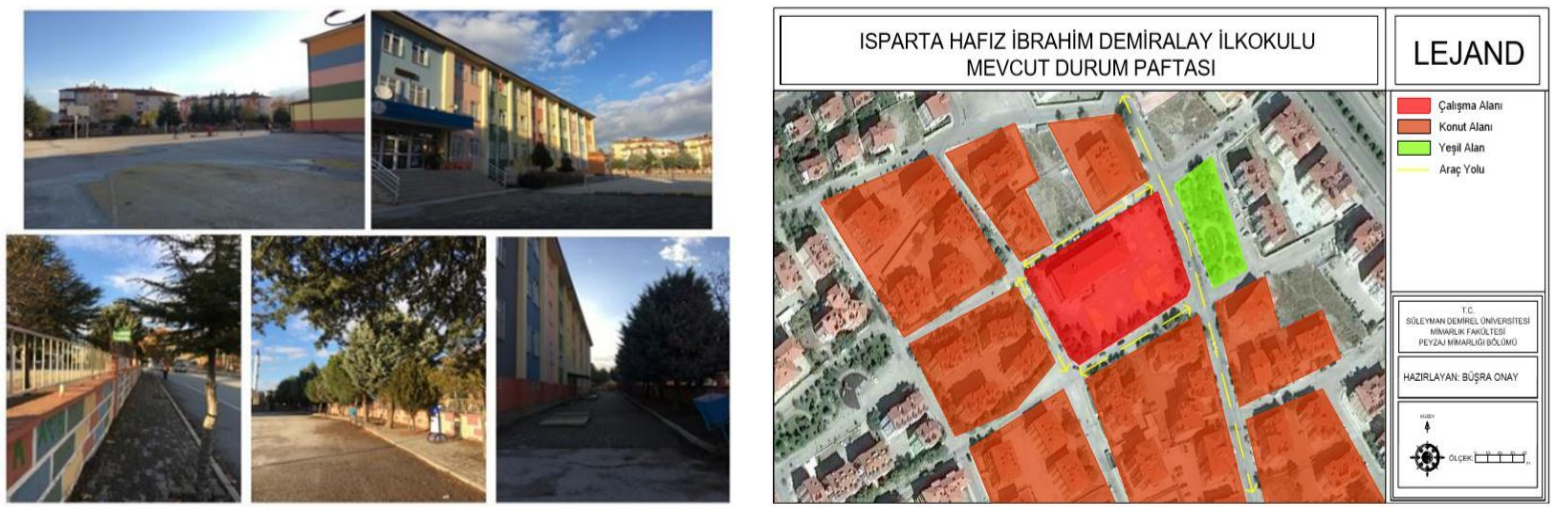

Şekil 2. Hafız İbrahim Demiralay İlkokulu’ndan görünümler ve konumu.

Isparta kentinde Modernevler Mahallesi'nde yer alan Gazi İlkokulu (Gİ), 2018 y1lında eğitim-öğretime başlamıştır. Okul bünyesinde toplam 929 öğrenci bulunmaktadır (URL1 2020). Bahçe genişliği $3444 \mathrm{~m}^{2}$ olan okulun kuzey cephesinde bir park yer alırken, diğer cephelerinde ise konutlar bulunmaktadır (Şekil 3). 

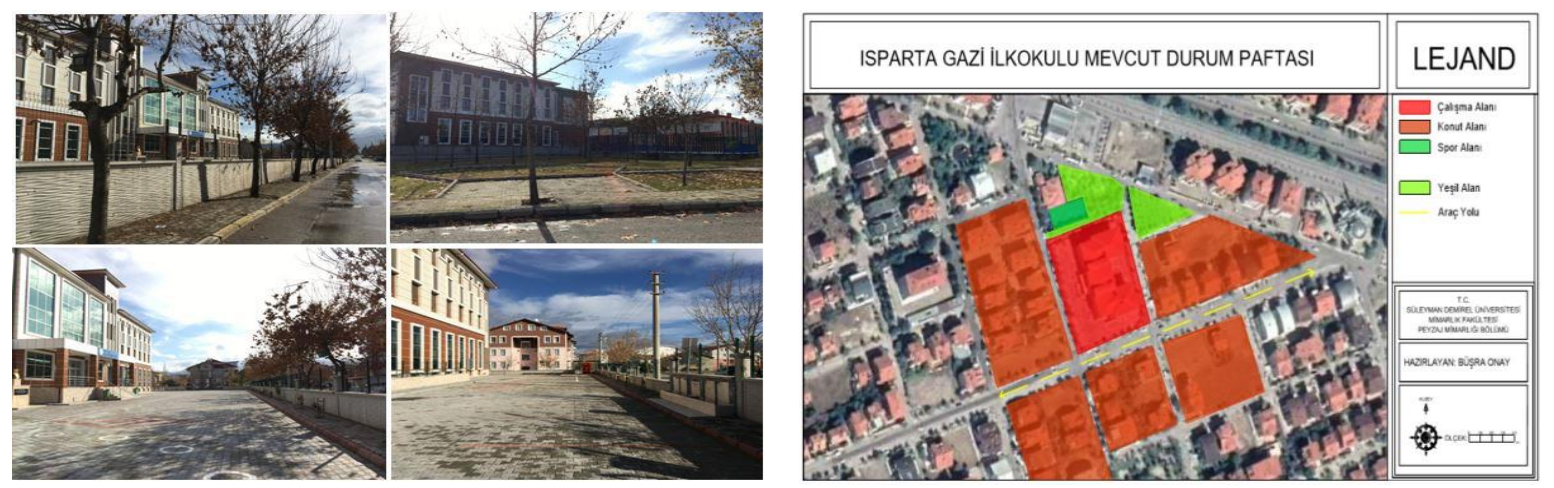

Şekil 3. Gazi İlkokulu’ndan görünümler ve konumu.

Kepeci Mahallesi'nde yer alan Ülkü İlkokulu'nun (Üİ) 695 öğrencisi bulunmaktadır (URL1 2020). 1818 m² genişliğe sahip olan okul bahçesinin çevresi incelendiğinde; kuzey ve kuzeydoğu cephelerinde iki adet okul bulunmaktadır. Diğer cephelerinde ise konutlar yer almaktadır (Şekil 4).
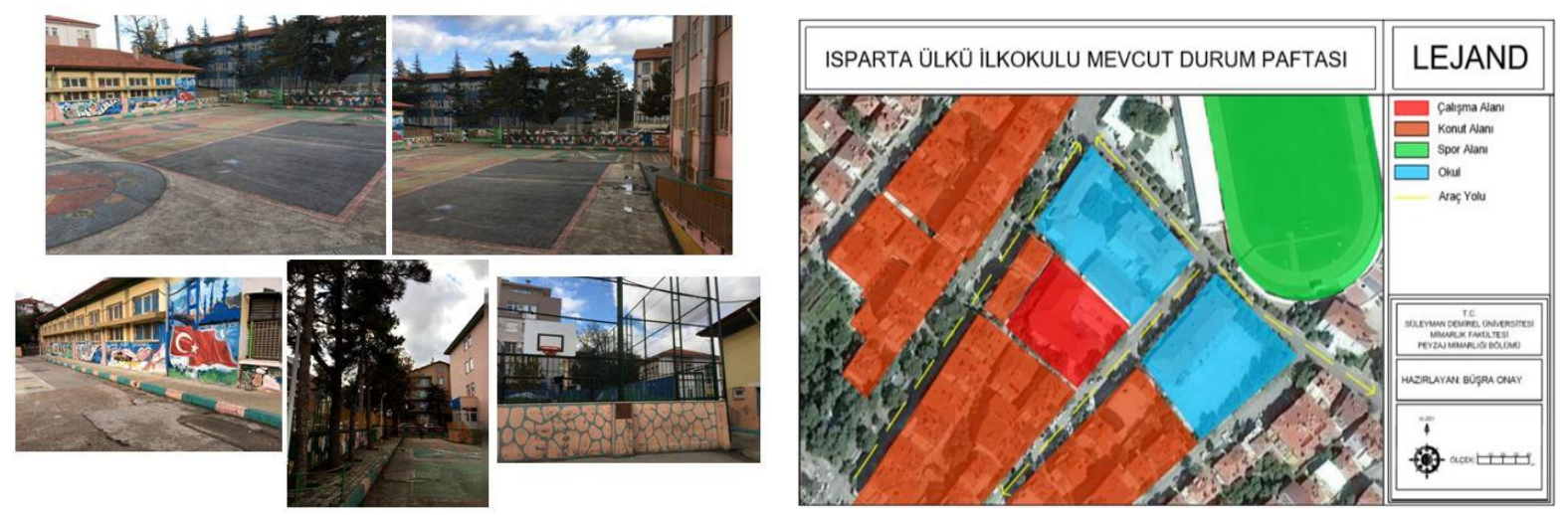

Şekil 4. Ülkü İlkokulu’ndan görünümler ve konumu.

\subsection{Metot}

Seçilen dört ilkokulda bahçe içi ve bahçe dışındaki gürültü düzeyleri belirlenmiştir. Ölçümlerde, PCE-NDL 10 marka ses ölçüm cihazı kullanılmıştır. Her ölçüm öncesinde $94 \mathrm{~dB}$ veya $114 \mathrm{~dB}$ değerinde olmak üzere çift kademeli kalibre yapabilme özelliğine sahip olan PCE-SC 42 Marka kalibratör ile cihazın kalibrasyonu sağlanmıştır. Meteoroloji Genel Müdürlüğü'nden elde edilen bilgiler doğrultusunda, TS ISO 1996-2 standartlarına uygun ölçüm yapabilmek için rüzgâr hızının $5 \mathrm{~m} / \mathrm{sn}$ 'den $(18 \mathrm{~km} / \mathrm{sa})$ yüksek olduğu günlerde ve ayrıca yağmur, kar yağması durumunda gürültü ölçümleri yapılmamıştır. Ölçümler, okullarda eğitim öğretimin devam ettiği hafta içi ve 08.30-17.00 saatleri arasında 5 dakika süre boyunca yapılmıştır. Ölçümlerin her noktada farklı gün ve saatlerde alınmasına dikkat edilmiştir. Ölçümler için her okulda teneffüste bahçe içinde, teneffüste bahçe dışında ve ders esnasında bahçe dışında olmak üzere belirlenen noktalarda üç ölçüm yapılmıştır. Bu noktalar belirlenirken, okul çevresinde yer alan; konut, park, ticaret alanı ve ulaşım vb gürültü kaynakları dikkate alınmıştır. Ölçüm yapılırken, gürültü ölçüm cihazı zeminden 1,5 m yükseklikte tutulmuştur ve çevresinde herhangi bir yansıtıcı yüzey olmamasına dikkat edilmiştir.

Ayrıca çalışma kapsamında, gürültü haritaları da oluşturulmuştur. Gerçek çevrenin ve gürültü kaynaklarının, sayısal ve görsel bir modelinin kurulması şeklinde ifade edilen gürültü haritaları, gürültü kontrolü ve planlama çalışmaları için temel hedeflerden birisidir (Kurra, 2009). Çalışmada; Mart, Nisan ve Mayıs aylarında ölçüm sonuçlarında elde edilen Leq değerleri ile gürültü haritaları oluşturulmuştur.

\section{Bulgular ve Tartışma}

\subsection{Gürültü Ölçümleri}

\subsubsection{Derste Bahçe Dışında Yapılan Gürültü Ölçümleri}

Çalışma alanı olarak seçilen okullarda ilk olarak öğrenciler ders esnasındayken bahçe dışındaki gürültüyü 
belirleyebilmek için ölçümler yapılmıştır. Tüm okulların çevresine bakıldığında, trafik kaynaklı gürültünün olduğu görülmektedir. Kurra (2009)'nın aktarımına göre Dünya Sağlık Örgütü (WHO) tarafından çevre gürültüsü için yayınlanan kılavuzda belirtilen değerlere göre okul bina dışı açık alanlarda limit değerinin $55 \mathrm{~dB}(\mathrm{~A})$ olması gerektiği, bu sınırın aşıldığı durumlarda ciddi rahatsızlık etkilerinin görülebileceği belirtilmektedir.

Naşide Halil Gelendost İlkokulu'nda Mart-Mayıs ayları arasında yapılan toplam 9 ölçüm değeri Şekil 5'te yer almaktadır. Elde edilen sonuçlara göre, gürültü ölçümünün en yüksek değerinin; öğrenciler derste bulunduğu zamanda okul bahçesi dışından alınan ölçüm için Mayıs ayının ilk haftası (65,9 dB(A)), en düşük değer ise Mart ayının üçüncü haftası olduğu tespit edilmiştir $(54,5 \mathrm{~dB}(\mathrm{~A}))$.

Hafız İbrahim Demiralay İlkokulu'nda Mart-Mayıs ayları arasında yapılan toplam 9 ölçüm değeri Şekil 6'da yer almaktadır. Elde edilen sonuçlara göre, gürültü ölçümünün en yüksek değeri; öğrenciler derste bulunduğu zamanda okul bahçesi dışından alınan ölçüm için Nisan ayının ilk haftası (68,6 dB(A)), en düşük değer ise Mayıs ayının ikinci haftasıdır $(57,5 \mathrm{~dB}(\mathrm{~A}))$.

Gazi İlkokulu'nda Mart-Mayıs ayları arasında yapılan toplam 9 ölçüm değeri Şekil 7'de yer almaktadır. Elde edilen sonuçlara göre, gürültü ölçümünün en yüksek değeri; öğrenciler derste bulunduğu zamanda okul bahçesi dışından alınan ölçüm için Mart ayının ilk haftası (75,5 dB(A)), en düşük değer ise Mart ayının ikinci haftasıdır $(44,3 \mathrm{~dB}(\mathrm{~A}))$.

Ülkü İlkokulu'nda Mart-Mayıs ayları arasında yapılan toplam 9 ölçüm değeri Şekil 8'de yer almaktadır. Elde edilen sonuçlara göre, gürültü ölçümünün en yüksek değeri; öğrenciler derste bulunduğu zamanda okul bahçesi dışından alınan ölçüm için Nisan ayının ilk haftası (69,5 dB (A)), en düşük değer ise Mart ayının birinci haftasıdır $(57,8 \mathrm{~dB}(\mathrm{~A}))$.

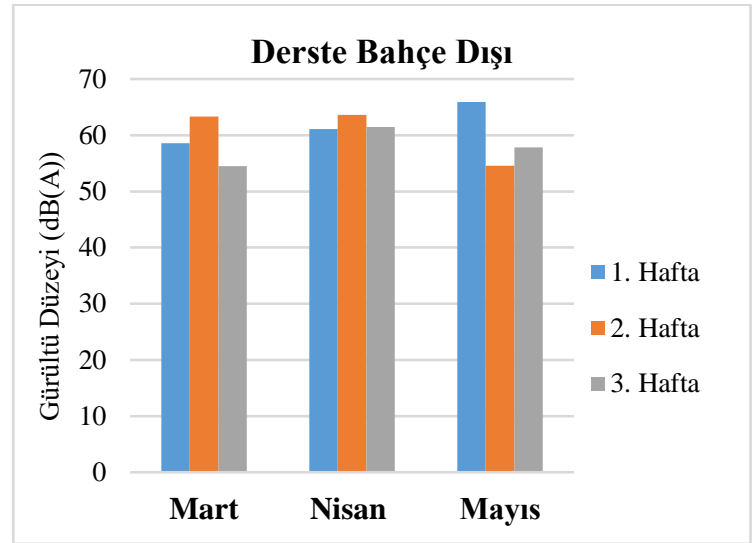

Şekil 5. Naşide Halil Gelendost İlkokulu ölçümleri.

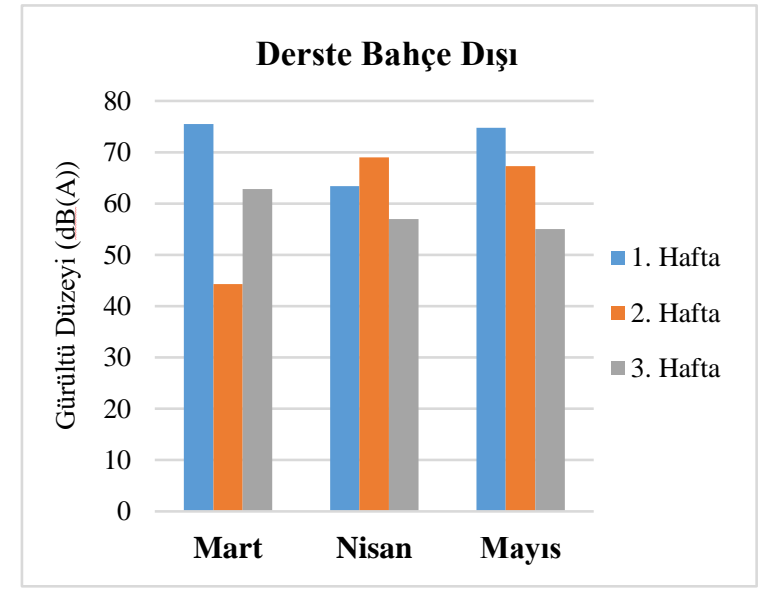

Şekil 7. Gazi İlkokulu ölçümleri.

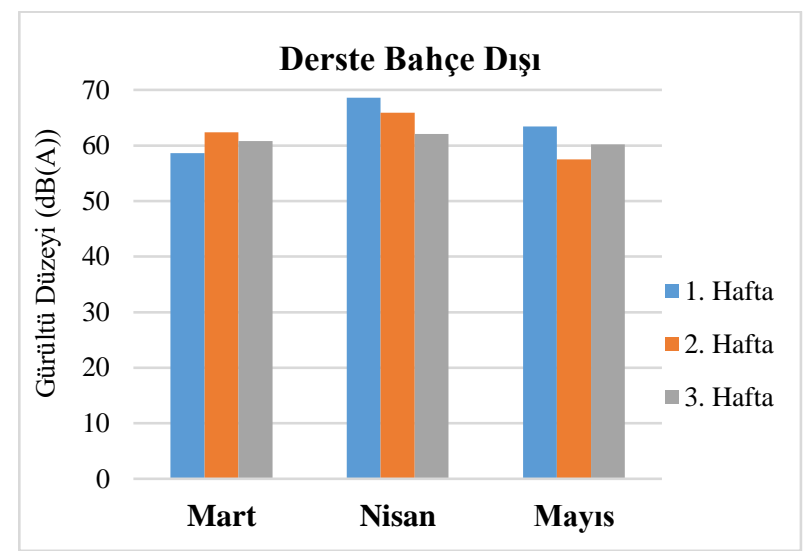

Şekil 6. Hafiz İbrahim Demiralay İlkokulu ölçümleri.

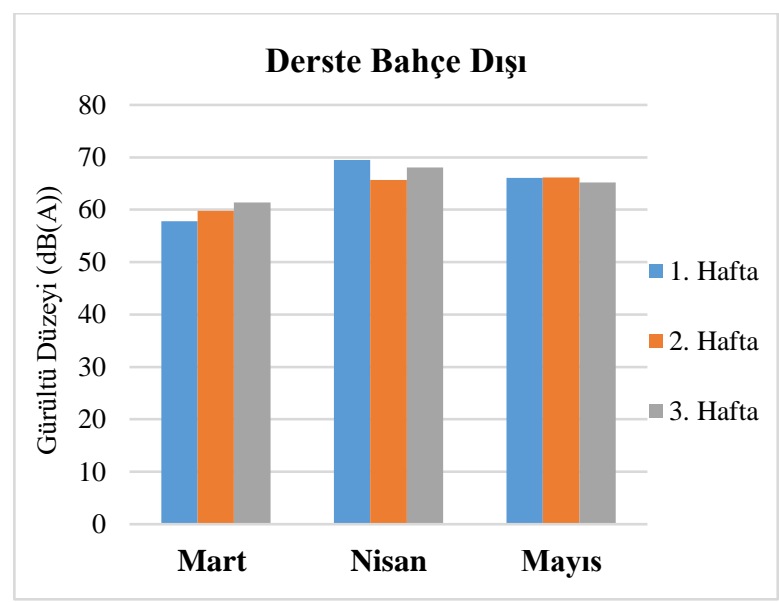

Şekil 8. Ülkü İlkokulu ölçümleri

Öğrenciler dersteyken bahçe dışında yapılan ölçümlerin genel sonuçlarına bakıldığında, Mart ayı içerisinde en 
yüksek gürültü değerine sahip olan okulun Gazi İlkokulu, en düşük gürültü değerine sahip olan okulun ise Naşide Halil Gelendost İlkokulu olduğu tespit edilmiştir. Nisan ayı içerisinde en yüksek gürültü değerine sahip olan okul Ülkü İlkokulu iken en düşük gürültü değerine sahip olan okul Naşide Halil Gelendost İlkokulu olmuştur. Mayıs ayında ise en yüksek gürültü değerine sahip olan okul Ülkü İlkokulu olurken en düşük gürültü değerine sahip olan okul Naşide Halil Gelendost İlkokulu olmuştur. Ölçüm değerleri ayrıntılı incelendiğinde, okulların bahçe dışı ölçümlerinin birbirine yakın olduğu görülmüştür. Ancak bütün aylar ele alındığında, en düşük gürültü değerine sahip olan okulun Naşide Halil Gelendost İlkokulu olduğu görülmektedir (Tablo 1).

Tablo 1. Derste bahçe dışı gürültü düzey ölçüm sonuçları $(\mathrm{dB}(\mathrm{A}))$.

\begin{tabular}{lllll}
\hline Okullar & Mart & Nisan & Mayıs & Genel Ort. \\
\hline Naşide Halil Gelendost İlkokulu & 58,8 & 62,1 & 59,4 & 60,1 \\
Hafız İbrahim Demiralay İlkokulu & 60,6 & 65,5 & 60,3 & 62,1 \\
Gazi İlkokulu & 60,8 & 63,1 & 65,7 & 63,2 \\
Ülkü İlkokulu & 59,6 & 67,7 & 65,8 & 64,4 \\
\hline
\end{tabular}

\subsubsection{Teneffüste Bahçe Dışında Yapılan Gürültü Ölçümleri}

Öğrenciler teneffüsteyken bahçe dışına ne kadar ses geldiğini belirlemek amacıyla yapılan ölçümlere göre; Naşide Halil Gelendost İlkokulu'nda Mart-Mayıs ayları arasında yapılan toplam 9 ölçüm değeri Şekil 9'da yer almaktadır. Elde edilen sonuçlara göre, gürültü ölçümünün en yüksek değeri; öğrenciler teneffüsteyken bahçe dışından alınan ölçüm için Mayıs ayının ilk haftası (74,7 dB(A)), en düşük değer ise Mayıs ayının ikinci haftasıdır $(53 \mathrm{~dB}(\mathrm{~A}))$.

Hafız İbrahim Demiralay İlkokulu'nda Mart-Mayıs ayları arasında yapılan toplam 9 ölçüm değeri Şekil 10'da yer almaktadır. Elde edilen sonuçlara göre, gürültü ölçümünün en yüksek değeri; öğrenciler teneffüsteyken bahçe dışından alınan ölçüm için Nisan ayının ikinci haftası (74,6 dB(A)), en düşük değer ise Mayıs ayının ikinci haftasidir $(67 \mathrm{~dB}(\mathrm{~A}))$.

Gazi İlkokulu'nda Mart-Mayıs ayları arasında yapılan toplam 9 ölçüm değeri Şekil 11'de yer almaktadır. Elde edilen sonuçlara göre, gürültü ölçümünün en yüksek değeri; öğrenciler teneffüsteyken bahçe dışından alınan ölçüm için Nisan ayının üçüncü haftası (80,7 dB(A)), en düşük değer ise Mayıs ayının üçüncü haftasıdır (61,5 $\mathrm{dB}(\mathrm{A}))$.

Ülkü İlkokulu'nda Mart-Mayıs ayları arasında yapılan toplam 9 ölçüm değeri Şekil 12'de yer almaktadır. Elde edilen sonuçlara göre, gürültü ölçümünün en yüksek değeri; öğrenciler teneffüsteyken bahçe dışından alınan ölçüm için Mayıs ayının birinci haftası (76 dB(A)), en düşük değer ise Mart ayının birinci haftasıdır (67,6 dB(A)).

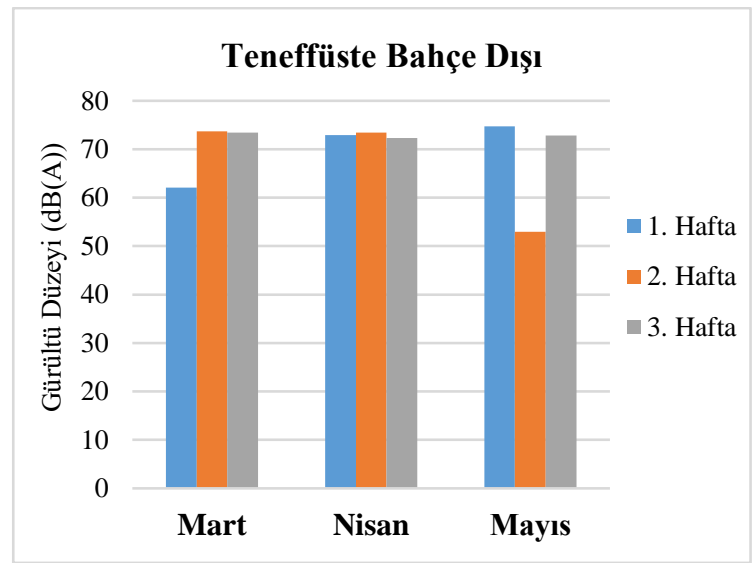

Şekil 9. Naşide Halil Gelendost İlkokulu ölçümleri.

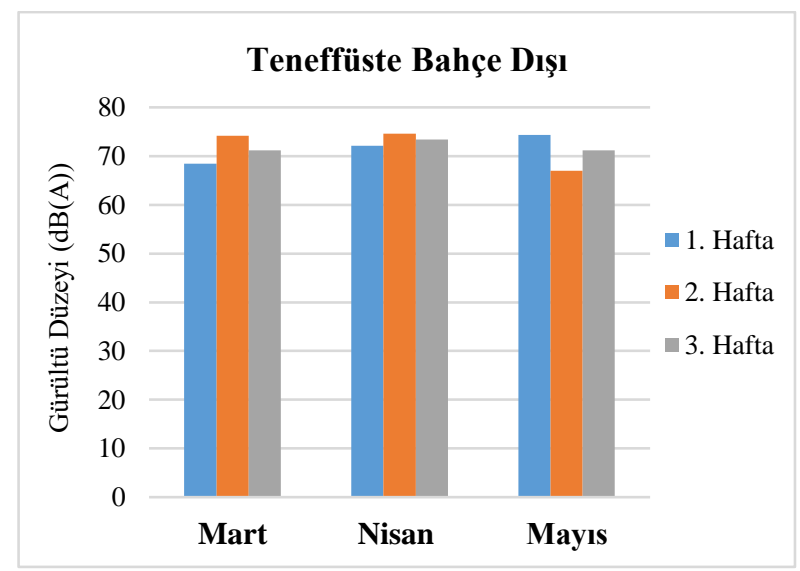

Şekil 10. Hafız İbrahim Demiralay İlkokulu ölçümleri. 


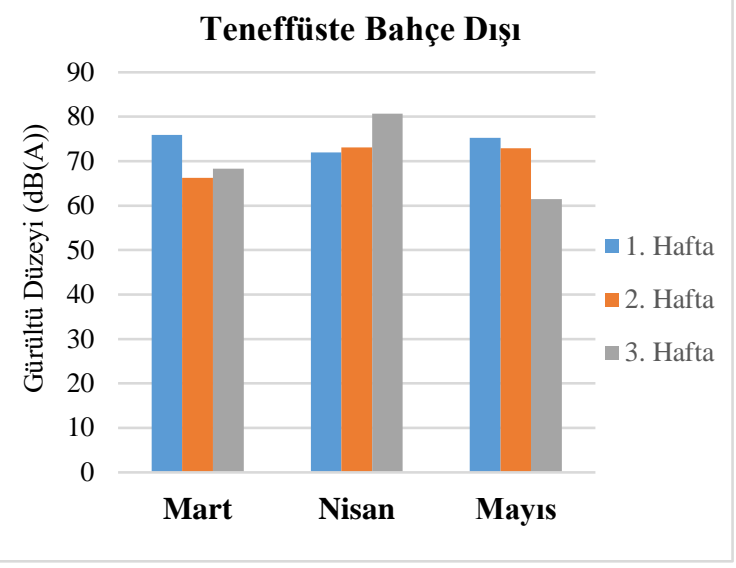

Şekil 11. Gazi İlkokulu ölçümleri.

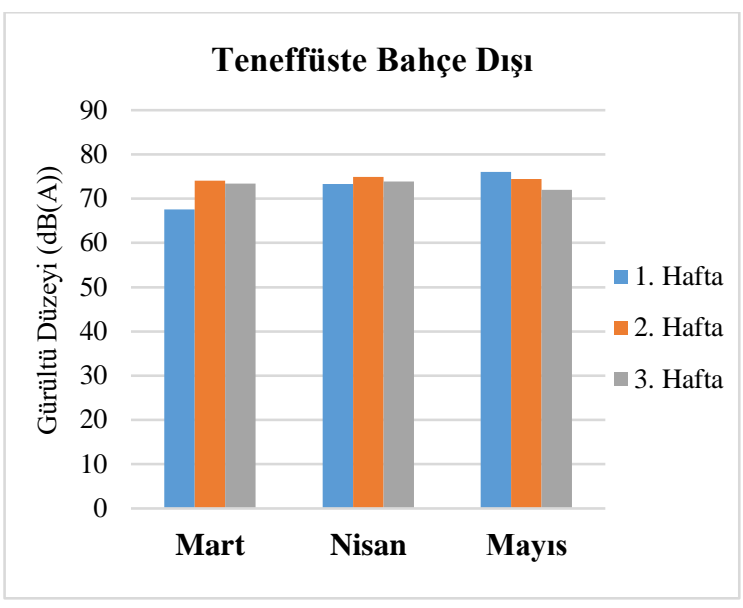

Şekil 12. Ülkü İlkokulu ölçümleri.

Öğrenciler teneffüsteyken bahçe dışında yapılan ölçümlerin genel sonuçlarına bakıldığında Mart ayı içerisinde en yüksek gürültü değerine sahip okul Ülkü İlkokulu olurken, en düşük gürültü değerine sahip okul Naşide Halil Gelendost İlkokulu olmuştur. Nisan ayı içerisinde en yüksek gürültü değerine sahip okul Gazi İlkokulu olurken en düşük gürültü değerine sahip okul Naşide Halil Gelendost İlkokulu olmuştur. Mayıs ayında ise en yüksek gürültü değerine sahip okul Ülkü İlkokulu olurken en düşük gürültü değerine sahip okul Naşide Halil Gelendost İlkokulu olmuştur. Ölçüm değerlerine bakıldığında okulların bahçe dışı ölçümlerinin birbirine yakın olduğu ve 55 dB'in üzerinde olduğu görülmüştür. Bütün aylarda en düşük gürültü değerine sahip olan okul Naşide Halil Gelendost İlkokulu olmuştur (Tablo 2).

Tablo 2. Teneffüste bahçe dışı ölçümleri genel sonuçları (dB(A)).

\begin{tabular}{lllll}
\hline Okullar & Mart & Nisan & Mayıs & Genel Ort. \\
\hline Naşide Halil Gelendost İlkokulu & 69,8 & 72,9 & 66,8 & 69,8 \\
Hafiz İbrahim Demiralay İlkokulu & 71,2 & 73,4 & 70,8 & 71,8 \\
Gazi İlkokulu & 70,1 & 75,3 & 69,9 & 71,8 \\
Ülkü İlkokulu & 71,7 & 74,0 & 74,1 & 73,3 \\
\hline
\end{tabular}

\subsubsection{Teneffüste Bahçe İçinde Yapılan Gürültü Ölçümleri}

Öğrenciler teneffüsteyken bahçe içinde ne kadar gürültü olduğunu tespit edebilmek amacıyla yapılan bu ölçümlere göre; Naşide Halil Gelendost İlkokulu'nda Mart-Mayıs ayları arasında yapılan toplam 9 ölçüm değeri Şekil 13'te yer almaktadır. Elde edilen sonuçlara göre, gürültü ölçümünün en yüksek değeri; öğrenciler teneffüsteyken bahçe içinde yapılan ölçüm için Mart aynının üçüncü haftası $(81,7 \mathrm{~dB}(\mathrm{~A}))$, en düşük değer ise Mayıs ayının ikinci haftasıdır (61,2 dB(A)).

Hafız İbrahim Demiralay İlkokulu'nda Mart-Mayıs ayları arasında yapılan toplam 9 ölçüm değeri Şekil 14'te yer almaktadır. Elde edilen sonuçlara göre, gürültü ölçümünün en yüksek değeri; öğrenciler teneffüsteyken bahçe içinde yapılan ölçüm için Mayıs aynının birinci haftası $(80,9 \mathrm{~dB}(\mathrm{~A}))$, en düşük değer ise Mart ayının birinci haftasidır $(65,2 \mathrm{~dB}(\mathrm{~A}))$.

Gazi İlkokulu'nda Mart-Mayıs ayları arasında yapılan toplam 9 ölçüm değeri Şekil 15'de yer almaktadır. Elde edilen sonuçlara göre, gürültü ölçümünün en yüksek değeri; öğrenciler teneffüsteyken bahçe içinde yapılan ölçüm için Mayıs aynının ikinci haftası (79 dB(A)), en düşük değer ise Mart ayının üçüncü haftasıdır (71,7 dB(A)).

Ülkü İlkokulu'nda Mart-Mayıs ayları arasında yapılan toplam 9 ölçüm değeri Şekil 16'da yer almaktadır. Elde edilen sonuçlara göre, gürültü ölçümünün en yüksek değeri; öğrenciler teneffüsteyken bahçe içinde yapılan ölçüm için Nisan aynının ikinci haftası (79,9 dB(A)), en düşük değer ise Mart ayının birinci haftasıdır (72,7 dB(A)). 


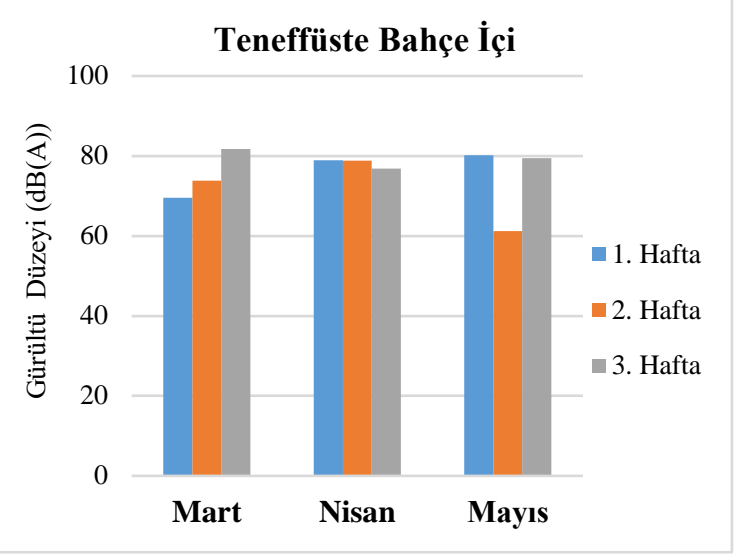

Şekil 13. Naşide Halil Gelendost İlkokulu ölçümleri.

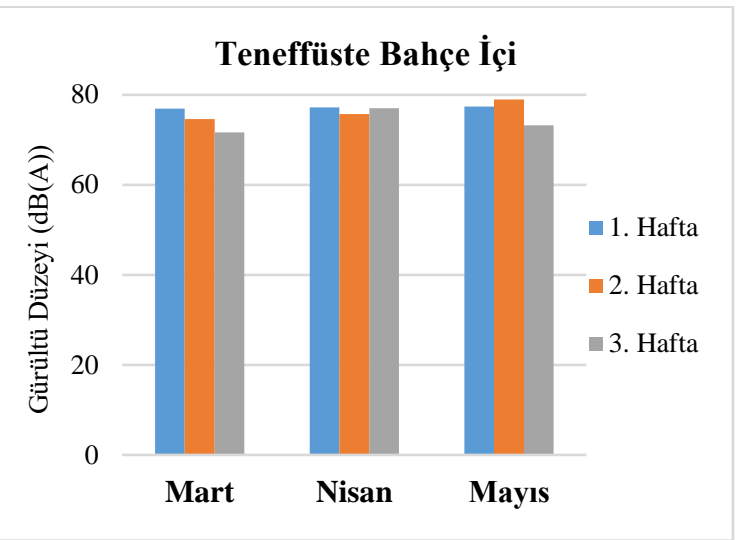

Şekil 15. Gazi İlkokulu ölçümleri.

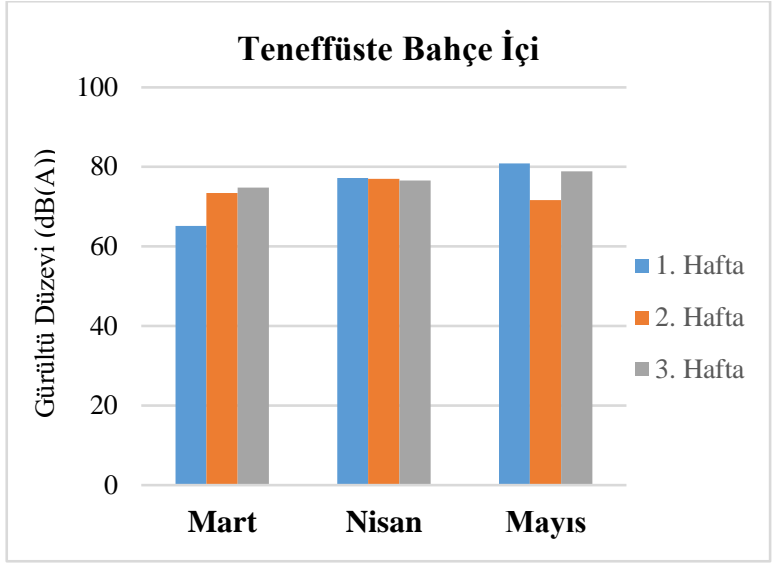

Şekil 14. Hafız İbrahim Demiralay İlkokulu ölçümleri.

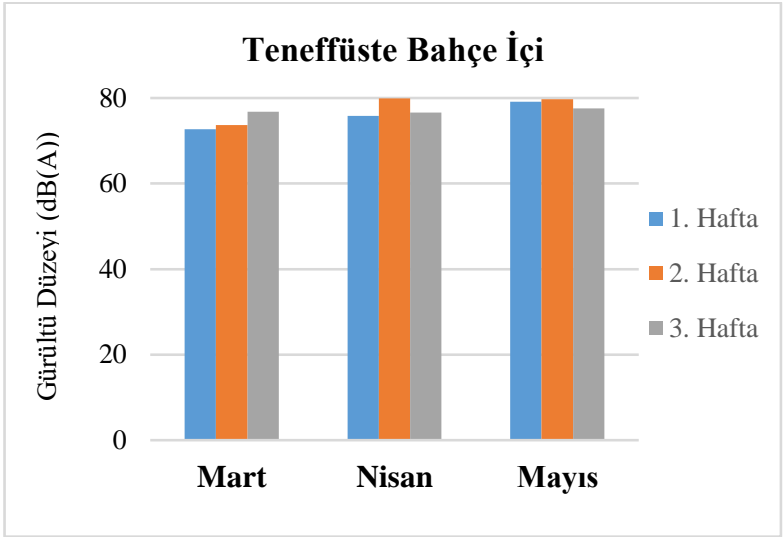

Şekil 16. Ülkü İlkokulu ölçümleri.

Öğrenciler teneffüsteyken bahçe içinde yapılan ölçümlerin genel sonuçlarına bakıldığında Mart ayı içerisinde en yüksek gürültü değerine sahip olan okul Naşide Halil Gelendost İlkokulu olurken en düşük gürültü değerine sahip olan okul Hafız İbrahim Demiralay İlkokulu olmuştur. Nisan ayı içerisinde en yüksek gürültü değerine sahip olan okul Naşide Halil Gelendost İlkokulu olurken en düşük gürültü değerine sahip olan okul Gazi İlkokulu oluştur. Mayıs ayında ise en yüksek gürültü değerine sahip olan okul Gazi İlkokulu olurken en düşük gürültü değerine sahip olan okul Naşide Halil Gelendost İlkokulu olmuştur (Tablo 3). Okulların bahçe içinde yapılan ölçümlerin genel ortalamalarına bakıldığında 55 dB'in üzerinde kaldığı görülmektedir.

Tablo 3. Teneffüste bahçe içi ölçümleri genel sonuçları $(\mathrm{dB}(\mathrm{A}))$.

\begin{tabular}{lllll}
\hline Okullar & Mart & Nisan & Mayıs & Genel Ort. \\
\hline Naşide Halil Gelendost İlkokulu & 75,0 & 78,2 & 73,6 & 75,6 \\
Hafiz İbrahim Demiralay İlkokulu & 71,1 & 76,9 & 77,2 & 75,1 \\
Gazi İlkokulu & 74,4 & 76,6 & 76,5 & 75,8 \\
Ülkü İlkokulu & 74,4 & 77,4 & 78,8 & 76,9 \\
\hline
\end{tabular}

Çalışılan 4 ilkokul incelendiğinde, öğrenciler dersteyken bahçe dışında yapılan ölçümde okulların çevresindeki kullanımların gürültüsüne bakılmıştır. Bu okullardan sadece Ülkü İlkokulu'nun çevresinde konut ve okullar yer almaktadır. Diğer okulların çevresi ise konutlarla çevrilidir. Ölçüm sonuçlarına bakıldığında, tüm okullarda gürültü seviyesi $55 \mathrm{~dB}(\mathrm{~A})$ 'nın üzerinde çıkmıştır. Bunun başlıca nedeni ise trafik gürültüsüdür. Nitekim, Delikanlı vd. (2014) tarafından trafikten kaynaklı gürültü kirliliğinin günümüzde yerleşim bölgelerinde oluşan gürültü kirliliği içerisinde önemli bir paya sahip olduğu vurgulanmıştır. Öğrenciler teneffüsteyken bahçe içinde ve bahçe dışında yapılan ölçümlere bakıldığında, gürültü seviyesi $55 \mathrm{~dB}(\mathrm{~A})$ 'nın üzerinde çıkmıştır. Bunun başlıca nedeni ise ilkokul öğrencilerinin oyun çağında olması ve teneffüste okul binasının büyük oranda boşalarak, bahçenin yoğun bir şekilde kullanılmasıdır. Polat ve Kırıkkaya (2004), Uskun vd. (2007), Şan (2010), Güremen (2012b), Bayazıt vd. 
(2013), Bhardwaj vd. (2013), Şahin vd. (2014), Bulunuz vd. (2017), Akabay ve Bulunuz (2018), Merkit (2019), Yılmaz (2019) tarafindan okul bahçelerinde yapılan çalışmalarda da benzer sonuçlar ortaya konulmuştur.

\subsection{Gürültü Haritaları}

Kentlerde gürültüden kaynaklanan baskının azaltılması ve şehir planlamalarında imar faaliyetlerine uygun alanların oluşturulmasında önemli bir gösterge olan gürültü haritaları, gürültü kirliliği ile mücadele kapsamında, gürültüye karşı hassas noktaların belirlenmesi ve bu noktaların karakterine uygun çözümlerin uygulanması amacıyla oluşturulmaktadır (Yalılı Kılıç ve Adalı, 2020). Bu bağlamda yapılan çalışmada; ders esnasında bahçe dışında, teneffüste bahçe dışında ve teneffüste bahçe içinde aylık gürültü haritaları oluşturulmuştur.

\subsubsection{Ders esnasında bahçe dışında yapılan ölçüm verileri ile oluşturulan aylık gürültü haritaları}

Öğrenciler dersteyken okul bahçesi dışında yapılan ölçümlerden elde edilen Leq değeri kullanılarak Mart, Nisan ve Mayıs ayları için gürültü haritaları oluşturulmuştur (1: NHGİ, 2: HíDİ, 3: Gİ, 4: Üİ) (Şekil 17, Şekil 18, Şekil 19).

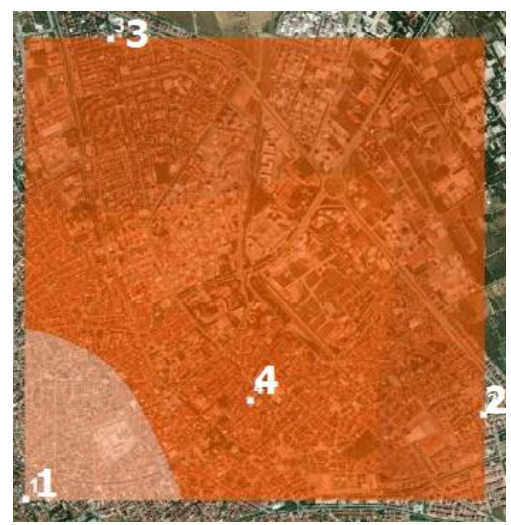

Şekil 17. Mart ayı gürültü haritası.

$58-59 \mathrm{~dB} \quad 59-60 \mathrm{~dB} \square 60 \mathrm{~dB}$

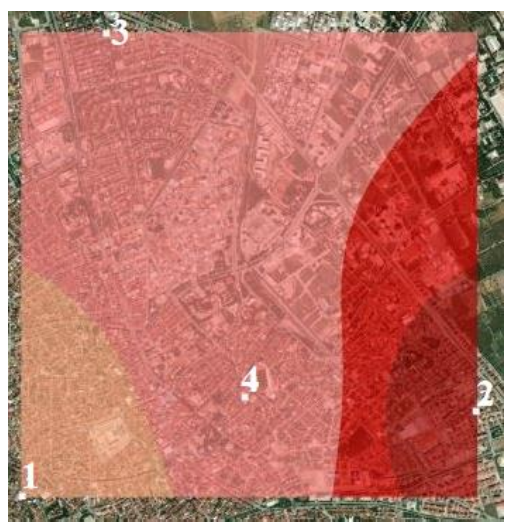

Şekil 18. Nisan ayı gürültü haritası.

$62 d B \square 62-63 d B \square 63-64 d B \square 64-65 d B$

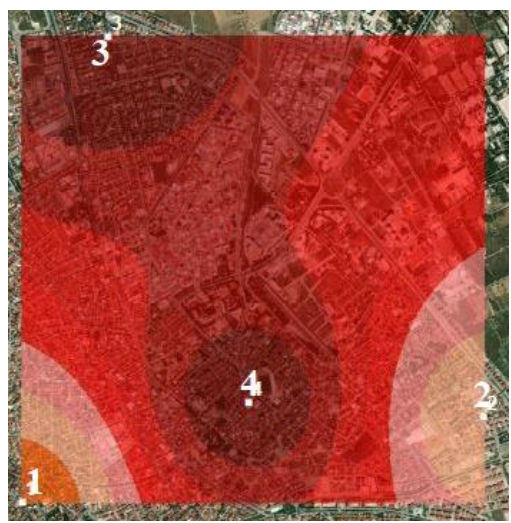

Şekil 19. Mayıs ayı gürültü haritası.

Mart ayı gürültü haritasına göre (Şekil 17), tüm okulların ölçümleri $55 \mathrm{~dB}(\mathrm{~A})$ 'nın üzerindedir. 2 numaralı Hafız İbrahim Demiralay İlkokulu (60,6 dB(A)) ile 3 numaralı Gazi İlkokulu'nun $(60,8 \mathrm{~dB}(\mathrm{~A}))$ diğer okullara göre daha yüksek değerlere sahip olduğu görülmektedir. Nisan ayında oluşturulan gürültü haritasına göre (Şekil 18), tüm okulların ölçümleri 55 dB(A)'nın üzerindedir. 2 numaralı Hafız İbrahim Demiralay İlkokulu'nun (65,5 dB(A)) diğer okullara göre daha yüksek değere sahip olduğu görülmektedir. Mayıs ayında oluşturulan gürültü haritasına göre (Şekil 19). tüm okulların ölçümleri $55 \mathrm{~dB}(\mathrm{~A})$ 'nın üzerindedir. 3 numaralı Gazi İlkokulu (65,7 dB(A)) ile 4 numaralı Ülkü İlkokulu'nun $(65,8 \mathrm{~dB}(\mathrm{~A}))$ diğer okullara göre daha yüksek değerlere sahip olduğu görülmektedir.

\subsubsection{Teneffüste bahçe dışında yapılan ölçüm verileri ile oluşturulan aylık gürültü haritaları}

Öğrenciler teneffüsteyken okul bahçesi dışında yapılan ölçümlerden elde edilen Leq değeri kullanılarak Mart, Nisan ve Mayıs ayları için gürültü haritaları oluşturulmuştur (1: NHGİ, 2: HİDİ, 3: Gİ, 4: ÜI) (Şekil 24, Şekil 25, Şekil 26).

Mart ayı gürültü haritasına göre (Şekil 20), tüm okulların ölçümleri 55 dB(A)’nın üzerindedir. 2 numaralı Hafız İbrahim Demiralay İlkokulu (71,2 dB(A)) ile 4 numaralı Ülkü İlkokulu'nun (71,7 dB(A)) diğer okullara göre daha yüksek değerlere sahip olduğu görülmektedir. Nisan ayında oluşturulan gürültü haritasına göre (Şekil 21), tüm okulların ölçümleri 55 dB(A)'nın üzerindedir. 3 numaralı Gazi İlkokulu'nun (75,3 dB(A)) diğer okullara göre daha yüksek değere sahip olduğu görülmektedir. Mayıs ayında oluşturulan gürültü haritasına göre ise (Şekil 22), tüm okulların ölçümleri $55 \mathrm{~dB}(\mathrm{~A})$ 'nın üzerindedir. 4 numaralı Ülkü İlkokulu'nun (74,1 dB(A)) diğer okullara göre daha yüksek değere sahip olduğu görülmektedir. 

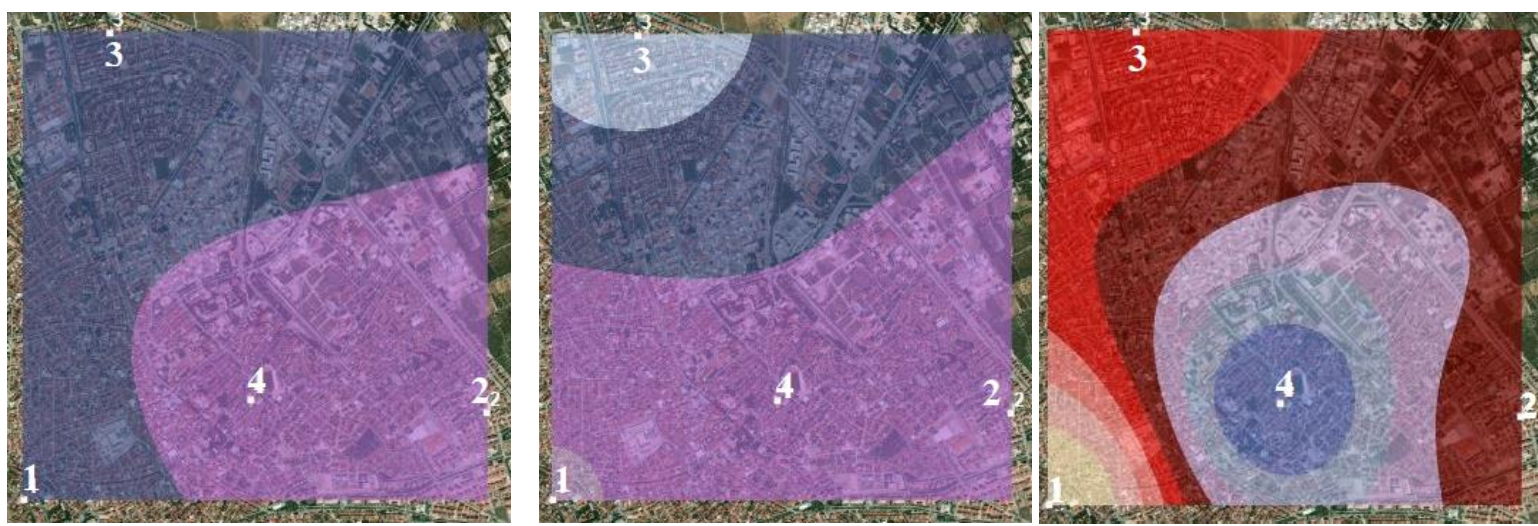

Şekil 20. Mart ayı gürültü haritası.

Şekil 21. Nisan ayı gürültü haritası.

Şekil 22. Mayıs ay1 gürültü haritası.

$69 d B \square 69-71 d B \square 71-72 d B \square 72-73 d B$

$$
\begin{gathered}
72 d B \square 72-73 d B \mid 73-74 d B \\
\square 74-75 d B \square 75-76 d B
\end{gathered}
$$

$\mid 66-67 d B \square 67-68 d B \square 68-69 d B \square 69-70 d B$

$70-71 d B \square 71-72 d B \square 72-73 d B \square 73-74 d B$

\subsubsection{Teneffüste bahçe içinde yapılan ölçüm verileri ile oluşturulan aylık gürültü haritaları}

Öğrenciler teneffüsteyken okul bahçesi içinde yapılan ölçümlerden elde edilen Leq değeri kullanılarak Mart, Nisan ve Mayıs ayları için gürültü haritaları oluşturulmuştur (1: NHGİ, 2: HİDİ, 3: Gİ, 4: Üİ) (Şekil 27, Şekil 28, Şekil 29).
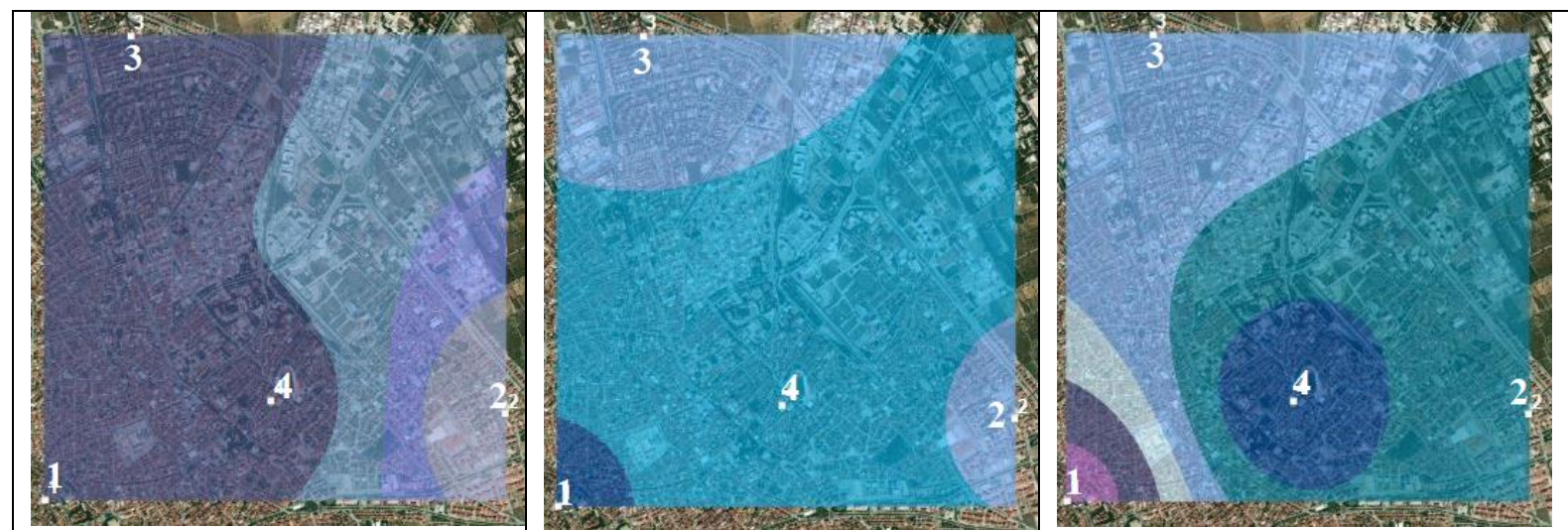

Şekil 23. Mart ayı gürültü haritası.

Şekil 24. Nisan ayı gürültü haritası.

Şekil 25. Mayıs ayı gürültü haritası.
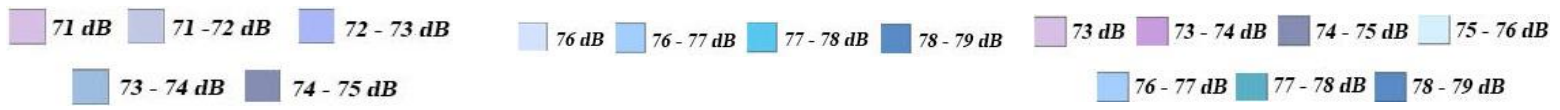

Mart ayı gürültü haritasına göre (Şekil 23), tüm okulların ölçümleri 55 dB(A)’nın üzerindedir. 3 numaralı Gazi İlkokulu $(74,4 \mathrm{~dB}(\mathrm{~A}))$ ile 4 numaralı Ülkü İlkokulu'nun $(74,4 \mathrm{~dB}(\mathrm{~A}))$ diğer okullara göre daha yüksek değerlere sahip olduğu görülmektedir. Nisan ayında oluşturulan gürültü haritasına göre (Şekil 24), tüm okulların ölçümleri 55 dB(A)'nın üzerindedir. 1 numaralı Naşide Halil Gelendost İlkokulu'nun (78,2 dB(A)) diğer okullara göre daha yüksek değere sahip olduğu görülmektedir. Mayıs ayında oluşturulan gürültü haritasına göre ise (Şekil 25) tüm okulların ölçümleri $55 \mathrm{~dB}(\mathrm{~A})$ 'nın üzerindedir. 4 numaralı Ülkü İlkokulu'nun $(78,8 \mathrm{~dB}(\mathrm{~A}))$ diğer okullara göre daha yüksek değere sahip olduğu görülmektedir.

\section{Sonuç ve Öneriler}

Öğrenme ve öğretme performansı üzerinde etkisi kanıtlanan gürültü ile ilgili WHO tarafından okul bahçesinde ve çevresinde $55 \mathrm{~dB}(\mathrm{~A})$ olarak sınır değeri belirlenmiştir. Çalışma yapılan okulların bahçe içinde ve bahçe dışında ölçülen gürültü seviyeleri incelendiğinde; $65 \mathrm{~dB}(\mathrm{~A})$ değerinin altındaki okullarda, uyku ve dinlenme bozukluklarına neden olan, rahatsızlık verici düzeyde; 66-85 $\mathrm{dB}(\mathrm{A})$ arasındakilerin ise rahatsız edici, ruhsal 
zararlar ve geçici duyma bozukluğu verecek düzeyde olduğu ve önlem alınması gerektiği görülmektedir. Bu kapsamda;

- Okul çevresindeki yollarda araçlardan kaynaklanan (korna vb) gürültüyü artıran unsurların yasaklanması ya da uyarıcı levhaların konulması,

- Okul çevresindeki yollarda araç hızını düşürmek için engellerin yapılması,

- İnsanlarda gürültü konusunda farkındalık oluşturmak ve duyarlılıklarını artırmak için bilgilendirme levhalarının asılması,

- Öğrencilere gürültü konusu ile ilgili duyarlılıklarını artırma amaçlı eğitim verilmesi,

- Şehir planlaması yapılırken okulların ana yollar üzerinde planlanmaması,

- Okulların yapım aşamasında bahçelerinde gürültü perdeleri için alanlar bırakılması ve

- Mevcut okulların bahçelerinde farklı malzemeler kullanılarak gürültüyü önleyici paneller ya da bitki perdeleri yapılması gibi öneriler gürültüyü azaltmak ya da önlemek konusunda yardımcı olacaktır.

Öneriler doğrultusunda, okul bahçelerinde yapılacak olan gürültü perdeleri hem fonksiyonel hem de estetik açıdan önem arz etmektedir. Gürültü perdelerinin tasarımı, doğru yapısal ve/veya bitkisel materyallerin kullanılması, planlama yapılırken okul bahçesi büyüklüklerinin uygun şekilde belirlenmesi planlama ve tasarım açısından oldukça önemlidir.

\section{Teşekkür}

Bu çalışma, Süleyman Demirel Üniversitesi, Bilimsel Araştırma Koordinatörlüğü’nün FDK-2018-6873 No`lu Proje tarafindan desteklenmiştir.

\section{Kaynaklar}

1. Akabay, H., Bulunuz, M. (2018). Okul İçi ve Okul Dış1 Gürültü Düzeylerinin Karşılaştırılması. Academy Journal of Educational Sciences, 2(1), 53-65.

2. Anonim (2019). Isparta İli 2018 Yılı Çevre Durum Raporu. Isparta Çevre ve Şehircilik Müdürlüğü, Isparta.

3. Bayazıt, N.T., Küçükçifçi, S., Şan, B. (2013). İlköğretim Okullarında Gürültüden Rahatsızlığın Alan Çalışmalarına Bağlı Olarak Saptanması. TTMD Dergisi, 37-48.

4. Bhardwaj, M., Baum, U., Markevych, I., Mohamed, A., Weinmann, T., Nowak, D., Radon, K. (2013). Are Primary School Students Exposed to Higher Noise Levels than Secondary School Students in Germany. International Journal of Occupational and Environmental Medicine, 4(1), 1-11.

5. Bulunuz, N., Bulunuz, M., Orbak, A. Y., Mutlu, N., Tavşanlı, Ö. F. (2017). An Evaluation of Primary School Students' Views About Noise Levels in School. International Electronic Journal of Elementary Education, 9(4), 725-740.

6. Delikanlı, N.E., Yücedağ, C., Kapdı, A. (2014). Bartın Kentinde Araç Trafiğinden Kaynaklı Gürültü Kirliliği Üzerine Bir Ön Çalışma. Bartın Üniversitesi Mühendislik ve Teknoloji Bilimleri Dergisi, 2, 21-39.

7. Demirci, D. (2011). Isparta Evleri. Isparta Valiliği İl Kültür ve Turizm Müdürlüğ̈̈, Isparta.

8. Ebrahim, S.E., Al-Naseri, S.K., Ali, S.H. (2017). Noise Pollution Assessment and Control in Selected Schools in Baghdad City. Association of Arab Universities Journal of Engineering Sciences, 3(24), 33-42.

9. Güremen, L. (2012a). İlköğretim Okullarında İç ve Dış Ortam İşitsel Konfor Koşullarının Kullanıcılardaki Etkisinin Değerlendirilmesi Üzerine Bir Çalışma Amasya Kenti Örneği. E-Journal of New World Sciences Academy, 7(3), 580-604.

10. Güremen, L. (2012b). Amasya Kentinde İlköğretim Okullarında İç ve Dış Çevre Gürültü Koşullarının Değerlendirilmesi. E-Journel of New World Sciences Academy - Engineering Science, 7(2), 415-435.

11. Kurra, S. (2009). Çevre Gürültüsü ve Yönetimi. Bahçeşehir Üniversitesi Yayınlarl, İstanbul.

12. Merkit, M. (2019). İlkokul Dördüncü Sınıflarda Gürültü Kirliliği Farkındalık Eğitimi Uygulamalarının Etkisinin İncelenmesi: İzmir Örneklemi. Bursa Uludağ Üniversitesi, Eğitim Bilimleri Enstitüsü, Yüksek Lisans Tezi, 99s, Bursa.

13. Polat, S., Buluş Kırıkkaya, E. (2004). Gürültünün Eğitim-Öğretim Ortamına Etkileri. XIII Ulusal Ĕ̆itim Bilimleri Kurultayı. 6-9 Temmuz, Malatya.

14. Şahin, K., Şahin, A., Bağcı, H. R. (2014). Sinop Şehri ve Yakın Çevresindeki Bazı Okullarda Gürültü Kirliliği. Osmanlı Hakimiyet Sahası Çalışmaları, 4(6), 20-31. 
15. Şan, B. (2010). Illköğretim Okullarında Gürültüden Rahatsılı̆̆ın Alan Araştırması ile Belirlenmesi. İstanbul Teknik Üniversitesi, Fen Bilimleri Enstitüsü, Yüksek Lisans Tezi, 501s, İstanbul.

16. Türkiye İstatistik Kurumu (2021). Isparta Nüfus http://www.tuik.gov.tr/PreTablo.do?alt_id=1059 (Erişim Tarihi: 07.08.2020).

17. URL-1 (2020). https://isparta.meb.gov.tr/ URL1 (Erişim Tarihi: Ocak, 2020).

18. Uskun, E., Nayir, T., Turkoglu, H., Kilinç, S., Kisioglu, A.N., Ozturk, M. (2007). Outdoor noise levels of primary schools in Isparta. Turkish Journal of Public Health, 5(1), 23-30.

19. Yalılı Kılıç, M, Adalı, S. (2020). İlkokul Çevresinde Gürültü Kirliliğinin Belirlenmesi: Bursa İli Örneği. Journal of the Institute of Science and Technology, 10 (3), 1607-1615.

20. Yılmaz, M. (2019). Illkokul 3. ve 4. Sınıflarda Okulda Gürültü Kirliliği Eğitimi Uygulamalarının Değerlendirilmesi. Bursa Uludağ Üniversitesi, Eğitim Bilimleri Enstitüsü, Yüksek Lisans Tezi, 130s, Bursa. 